\title{
Article \\ Cathodic Water Enhances Seedling Emergence and Growth of Controlled Deteriorated Orthodox Seeds
}

\author{
Kayode Fatokun ${ }^{1, *}$, Richard P. Beckett ${ }^{2,3}{ }^{\mathbb{D}}$, Boby Varghese ${ }^{1}$ and Norman W. Pammenter ${ }^{1}$ \\ 1 School of Life Sciences, University of KwaZulu-Natal, Westville Campus, Private Bag X54001, \\ Durban 4000, South Africa; varghese@ukzn.ac.za (B.V.); pammente@ukzn.ac.za (N.W.P.) \\ 2 School of Life Sciences, University of KwaZulu-Natal Pietermaritzburg, Private Bag X01, \\ Pietermaritzburg 3209, South Africa; rpbeckett@gmail.com \\ 3 Open Lab 'Biomarker', Kazan (Volga Region) Federal University, Kremlevskaya str. 18, 420008 Kazan, Russia \\ * Correspondence: kayfatokun@yahoo.com
}

Citation: Fatokun, K.; Beckett, R.P.; Varghese, B.; Pammenter, N.W.

Cathodic Water Enhances Seedling Emergence and Growth of Controlled Deteriorated Orthodox Seeds. Plants 2021, 10, 1170. https://doi.org/ $10.3390 /$ plants10061170

Academic Editor: Maurizio Cocucci

Received: 8 April 2021

Accepted: 15 May 2021

Published: 9 June 2021

Publisher's Note: MDPI stays neutral with regard to jurisdictional claims in published maps and institutional affiliations.

Copyright: (c) 2021 by the authors. Licensee MDPI, Basel, Switzerland. This article is an open access article distributed under the terms and conditions of the Creative Commons Attribution (CC BY) license (https:// creativecommons.org/licenses/by/ $4.0 /)$.
Abstract: All orthodox seeds eventually deteriorate during storage, a well-known problem in seed banking. Here we used a greenhouse study to test if priming deteriorated seeds with cathodic water can improve the emergence and subsequent seedling growth of three South African tree species, Bolusanthus speciosus, Combretum erythrophyllum and Erythrina caffra. Other priming solutions investigated were calcium magnesium (CaMg) solution and deionized water. In the present study, seeds were subjected to an artificial deterioration by increasing their water content to $14 \%$ and keeping them at $40{ }^{\circ} \mathrm{C}$ and $100 \%$ RH until they had lost $50 \%$ of their germination under laboratory conditions. Fresh and deteriorated seeds were primed with cathodic water, CaMg solution and deionized water, with non-primed fresh and deteriorated seeds as controls. Controlled deterioration significantly reduced total emergence and the biomass and photosynthetic parameters of the resulting seedlings. In one species (Bolusanthus speciosus), priming the deteriorated seeds with cathodic water significantly improved emergence parameters. However, in all species cathodic water significantly improved the total biomasses and other growth parameters of the seedlings derived from deteriorated seeds. Priming with CaMg solution and deionized water had little effect on emergence and while improving the growth of seedlings derived from deteriorated seeds, they were less effective than cathodic water. In fresh seeds, priming with all solutions resulted in small improvements in some parameters. Controlled deterioration of fresh seeds reduced the membrane stability index (MSI) in two of the three species and in all species increased the levels of the lipid oxidation products MDA and 4-HNE. Priming deteriorated seeds with cathodic water increased the MSI and reduced the MDA contents in all species and the 4-HNE content in one species. Other priming solutions were generally less effective in ameliorating oxidative stress. Results suggest that the strong antioxidative properties of cathodic water can explain its ability to ameliorate deterioration. In conclusion, the present study shows that priming with cathodic water is an effective way of invigorating deteriorated orthodox seeds and that it may have considerable potential in orthodox seed conservation.

Keywords: cathodic water; deterioration; membrane; orthodox seeds; priming

\section{Introduction}

Orthodox seeds need to be stored in the short term so that they can produce high quality plants in the next growing season. Seeds also must be stored in long-term base collections with the aim of conserving genetic resources so that germplasm can be maintained and used in future breeding programs and for restoring wild populations [1]. Seed quality, therefore, must be maintained over extended periods. However, no matter how good the conditions, all seeds undergo deterioration (also known as aging) during long-term storage, which leads to a decline in seed germination, seedling emergence and later plant growth [2]. The reduction in "performance" is of considerable concern with respect to the 
long-term conservation of genetic diversity, both of wild species and in species important in the agricultural and horticultural sectors [1].

A major cause of aging is oxidative stress. During storage, seeds accumulate reactive oxygen species (ROS) such as superoxide $\left(\mathrm{O}_{2}{ }^{-}\right)$, hydrogen peroxide $\left(\mathrm{H}_{2} \mathrm{O}_{2}\right)$ and the hydroxyl radical $(\cdot \mathrm{OH})[3]$. ROS attack many biomolecules and in particular the lipids in the cell membrane. Seeds have internal protective mechanisms such as antioxidant enzymes, including superoxide dismutase (SOD) and catalase (CAT), to counter the damaging effects of ROS. However, as deterioration progresses, the ability of these internal protective mechanisms becomes overwhelmed and damage can occur. Lipid peroxidation is believed to be a significant factor in seed deterioration and principal among the final products of lipid peroxidation are 4-hydroxynonenal (4-HNE) and malondialdehyde (MDA) [4]. The presence of 4-HNE and MDA indicates that the cell membrane may have become permeable and that solutes may leak from the cell. Clear evidence now exists that losses in membrane integrity are a result of the uncontrolled production of ROS [5-7]. While seeds suffering oxidative stress will probably display reduced germination and emergence, in addition "hangover effects" of deterioration may be carried through to later growth stages of the plant. Seedlings of deteriorated seeds may display reduced photosynthesis and transpiration, slower growth and ultimately lower yields (for review see [8]). Thus, even if poor quality seeds germinate or emerge, the quality of plants generated from such seeds is not guaranteed.

Seed invigoration, although sometimes used interchangeably with seed priming, is an umbrella term of treatments that can improve the germination and field performance of a given seed lot [1]. It is basically a pre-sowing technique used to improve germination and seedling growth or to facilitate the performance of seeds the time of sowing $[1,9]$. Seed invigoration includes pre-sowing hydration treatments [10-12], low-molecular-weight osmo-protectant seed treatments [9], coating technologies [13] and more recently, presowing dry heat treatment [11]. The focus of seed invigoration is to improve germination, reduce seedling emergence time and increase uniformity of emergence and protection of seeds from biotic and abiotic factors during the critical phases of seedling establishment.

There are essentially two ways of priming seeds. In the first, the hydrated seeds are sown after a period of hydration [14], reducing the lag time of imbibition [15,16]. Usually when seeds are not re-dried, they are placed in solutions with a high osmotic potential to prevent the seeds from taking in enough water to enter phase III (initiation of growth) of hydration. The notion is to hold the seeds in phase II (reactivation of metabolism) and therefore essentially keeping the seed within the lag phase [9]. During this period, the seeds are metabolically active and stored reserves are converted for use during germination. After imbibition, the seeds are removed from the priming solution, rinsed with water and sown in the field [14,17]. However, it is also possible to dry seeds before they are sown. In both methods, the priming hydration causes activation or repair of enzymes [17]. If seeds are dried after priming, it has been suggested that damaged seeds undergo repair during drying, possibly explaining the improved performance of primed seeds [17]. Numerous advantages of priming orthodox seeds have been reported for plants from around the world $[18,19]$. Primed seeds can exhibit faster germination when re-imbibed under normal or stress conditions. Priming has been shown to benefit a range of crops from tropical regions, for example Oryza sativa, Zea mays, Sorghum bicolor and Cajanus cajan [14,20].

In this study, we tested the ability of a novel seed priming agent, cathodic water, to ameliorate deterioration in three South African tree species, Bolusanthus speciosus, Combretum erythrophyllum and Erythrina caffra. Cathodic water is an electrolyzed form of calcium magnesium $(\mathrm{CaMg})$ solution [21]. Cathodic water has strong antioxidative properties and in addition to the benefits conferred by conventional priming solutions, may counteract the damage caused by ROS. Our study therefore brings the concept of electrochemistry into plant germplasm conservation and crop establishment and production. Preliminary reports from our group showed that under laboratory conditions, priming with cathodic water had beneficial effects on the germination of deteriorated seeds from a variety of 
species [22,23]. However, its effects on seedling emergence and subsequent growth of the resulting seedlings have not been properly documented. Rather than use naturally aged seeds, here we used controlled deterioration, involving exposing seeds to a predetermined aggravated temperature and humidity $[24,25]$. This enabled us to deteriorate the seeds of all species to the same extent.

\section{Materials and Methods}

\subsection{Study Area and Acquisition of Plant Materials}

Seed aging and germination were carried out in the laboratories of the Plant Germplasm Conservation Research Unit, University of KwaZulu-Natal, Durban, South Africa. Plants were grown in a greenhouse of same School (Average temperature: $23.5^{\circ} \mathrm{C}$, relative humidity: $67 \%$.

Potting mix and multifeed fertilizer used in this study were purchased from Silverhill seeds, Cape Town, South Africa. Initial germination tests carried out on the seeds indicated that both B. speciosus and E. caffra have seed coat imposed dormancy, while C. erythrophyllum also has a form of dormancy imposed by the samara covering the seed. Nicking was carried to break E. caffra and B. speciosus dormancy, while dormancy in C. erythrophyllum was broken by removing the samara covering the seeds. The initial water contents of the species were raised to $14 \%$ using vapor chambers. The seeds were then sealed in airtight glass jars and kept in a digital oven (Series 2000 , Scientific, USA) at $40{ }^{\circ} \mathrm{C}$ and $100 \%$ relative humidity. Samples were taken every few days to assess the time needed to achieve a $50 \%$ reduction in germination.

\subsection{Preparation of Cathodic Water}

A solution containing $1 \mu \mathrm{M} \mathrm{CaCl}_{2}$ and $1 \mu \mathrm{M} \mathrm{MgCl}_{2}$ in deionized water known as calcium magnesium (CaMg) solution was prepared, autoclaved and stored at $-5^{\circ} \mathrm{C}$ until needed. The $\mathrm{pH}$ of $\mathrm{CaMg}$ solution was 7 .

Cathodic water was prepared by electrolyzing the CaMg solution [26]. Two $200 \mathrm{~mL}$ glass beakers were filled with CaMg solution and platinum electrodes were immersed in the solution, the anode in one beaker and the cathode in the other. To form a complete circuit, an agar-based potassium chloride ( $\mathrm{KCl}$ ) salt bridge (a $\mathrm{U}$ shaped glass tube) was inserted to connect the two beakers. The $\mathrm{CaMg}$ solution was electrolyzed by applying a $60 \mathrm{~V}$ potential difference using a Bio-Rad Powerpac (BioRad, Hercules, CA, USA) at $400 \mathrm{~mA}$ for $1 \mathrm{~h}$ at room temperature. The electrolysis yielded anodic (oxidizing) water with a $\mathrm{pH}$ of approximately (c.) 2.4, and cathodic (reducing) water with a $\mathrm{pH}$ of $c$. 11.2. The anodic water was discarded while the cathodic water was used within one hour of preparation.

\subsection{Seed Priming, Plant Management and Data Collection}

To prime the seeds ( 50 seeds per treatment) they were placed between 20 layers of single-ply paper towel, which was placed on aluminum foil. Priming solutions (50 mL) were poured onto these paper towels. The aluminum foil containing the seeds was placed in plastic pouches and after $24 \mathrm{~h}$, just before radicle emergence, the seeds were dried back to their original masses under ambient laboratory conditions for $7 \mathrm{~d}$ and kept at $4{ }^{\circ} \mathrm{C}$ in air-tight bottles until required. There were eight treatments: six seed priming treatments and two controls. The seed priming treatments were: aged seeds primed with cathodic water (ASP.CW); aged seeds primed with CaMg solution (ASP.CM); aged seeds primed with distilled water (ASP.DW); fresh seed (unaged) primed with cathodic water (FSP.CW); fresh seeds primed with CaMg solution (FSP.CM); fresh seeds primed with distilled water (FSP.DW) and two controls; unprimed fresh seeds (FSC) and unprimed aged seeds (ASC). Each treatment was replicated four times $(n=200)$. Note: $n=$ total number of seeds used per treatment.

To test emergence and subsequent seedling growth, a completely randomized experimental design was used. The plants were grown in $2 \mathrm{~L}$ pots containing $800 \mathrm{~g}$ of peat-based potting mix and watered as required. After $C D$ and priming, five seeds were planted in 
each pot, with four pots per treatment $(n=20)$ arranged in a completely randomized design. Emerged seedlings were counted and recorded daily. Thinning was done at 4 weeks after planting to reduce the number of plants per pot from five to one. Plants were irrigated when required throughout the period of the experiment. Grovida multifeed water soluble fertilizer was used to supply nutrients to the growing plants at $1 \mathrm{~g} \mathrm{~L}^{-1}$ weekly The composition of the fertilizer was N, P, K, S and Mg at 193, 83, 153, 6.1 and $4.6 \mathrm{~g} \mathrm{~kg}^{-1}$, respectively. The fertilizer also contained the micronutrients $\mathrm{Zn}, \mathrm{B}, \mathrm{Mo}, \mathrm{Fe}, \mathrm{Mn}$ and $\mathrm{Cu}$ at 700, 1054, 63, 751,273 and $75 \mathrm{mg} \mathrm{kg}^{-1}$, respectively. Physiological parameters (photosynthesis, transpiration and chlorophyll fluorescence) were measured 8 weeks after planting (WAP) and chlorophyll content 10 weeks after planting (WAP). The study was terminated at 12 WAP. The plants were harvested and separated into root, stem and leaves. The plant parts were measured and the leaves were counted. All plant parts were oven dried at $65^{\circ} \mathrm{C}$ to constant mass. The oven-dried plant parts were weighed and recorded.

\subsubsection{Emergence}

Seedling emergence counts were taken daily until constant counts were achieved. The value was expressed in percentage. The following were determined from the emergence data taken: First Day of Emergence (FDE), Final Emergence Percentage (FEP), Mean Emergence Time (MET). MET was calculated according to the equation of [27]: $\mathrm{MET}=\sum \mathrm{Dn} / n$, where $n$ is the number of emerged seedlings on day $\mathrm{D}$ and $\mathrm{D}$ is the number of days counted from the beginning of seedling emergence.

Emergence Index (EI) is also called speed of emergence and it was calculated using the method of [28].

$$
=\frac{\text { Number of emerged seedlings }}{\text { Days of first count }}+\ldots+\frac{\text { Number of emerged seedlings }}{\text { Days of final count }}
$$

Uniformity of Emergence (UE) was calculated using the formula of [29], $=\sum n /\left[(T-t)^{2} n\right]$ ( $n$ is the number of emerged seedlings counted on a particular day, $t$ is the time (number of days) beginning from day $0, \mathrm{~T}$ is the MET.

\subsubsection{Leaf Chlorophyll Content and Chlorophyll Fluorescence}

Leaf chlorophyll content was measured on the third, fourth and fifth leaves counting from the terminal bud using a SPAD chlorophyll meter (model SPAD-502; Minolta Corp., Ramsey, NJ, USA). Three measurements were taken on each leaf at 10 weeks of growth. The chlorophyll content was estimated as the mean of the 9 readings and expressed as the chlorophyll content index (CCI).

Chlorophyll fluorescence was measured using a Li-Cor 6400XT portable photosynthesis measuring system (Li-Cor, Lincoln, NE, USA). Chlorophyll fluorescence transients were measured on the third leaf from the terminal bud across all treatments and replicates at 8 weeks after planting. Measurements were taken after the plants were dark adapted for $40 \mathrm{~min}$. $\mathrm{Fv} / \mathrm{Fm}$, the ratio of variable ( $\mathrm{Fv})$ to maximum fluorescence (Fm), was used as a measure of potential photochemical efficiency of photosystem II (PSII).

\subsubsection{Photosynthetic Capacity—Steady-State Gas Exchange}

Gas exchange was measured with a Li-Cor 6400 portable photosynthesis measuring system, fitted with a standard chamber and configured as an open system (Li-Cor, Lincoln, NE, USA). Measurements were taken at 8 weeks after planting across all treatments and replicates. Instantaneous measurement of leaf-based $\mathrm{CO}_{2}$ assimilation and transpiration rates were carried out at a $\mathrm{CO}_{2}$ concentration of $400 \mu \mathrm{mol} \mathrm{CO}_{2} \mathrm{~mol}^{-1}$, a light intensity of $1000 \mu \mathrm{mol} \mathrm{m}{ }^{-2} \mathrm{~s}^{-1}$ and a temperature of $25^{\circ} \mathrm{C}$; measurements were taken between 11:00 am to 2:00 pm when conditions were typically most stable. The measurements were taken on fully expanded, non-senescing leaves. Three measurements were taken per plant on the third, fourth and fifth leaves from the terminal bud. The mean of these three measurements was used at the average rate of photosynthesis for each plant. 


\subsubsection{Harvesting and Post-Harvest Data Collection}

Shoot heights were measured using a meter rule at $12 \mathrm{WAP}$ and then plants were carefully pulled out of the potting mix to avoid damage to the roots. Potting mix which adhered to the roots was removed using tap water. The lengths of the roots were measured, the number of leaves was counted and the leaf area was measured with a leaf area meter (CI-202 Area Meter, CID, Inc., Camas, WA, USA). The plants were subsequently separated into leaves, stems and roots. The plant parts (root, stem and leaves) were oven dried at $65^{\circ} \mathrm{C}$ until constant mass and then weighed.

\subsection{Determination of MDA and $4 H N E$ Contents in Seeds}

In a separate experiment, fresh and deteriorated seeds were hydrated in the range of solutions as described above and at about the end of phase II of the seed hydration (18 h (B. speciosus) and $20 \mathrm{~h}$ (C. erythrophyllum and E. caffra)). One gram of seeds was homogenized in $5 \mathrm{~mL}$ of $20 \%(w / v)$ trichloro acetic acid (TCA) consisting of $0.5 \%(w / v)$ thiobarbituric acid (TBA). The homogenate was then incubated for $30 \mathrm{~min}$ at $95{ }^{\circ} \mathrm{C}$ [30], after which it was placed in an ice bath for $10 \mathrm{~min}$ and thereafter centrifuged at $10,000 \times \mathrm{g}$ for $10 \mathrm{~min}$. The absorbance of the supernatant was read at $600 \mathrm{~nm}$ using PowerWave ${ }^{\mathrm{TM}}$ microplate spectrophotometer (BioTek Instruments, Inc, Winooski, VT, USA). The content of MDA was calculated using the extinction coefficient of $155 \mathrm{mM}^{-1} \mathrm{~cm}^{-1}$. Content of MDA was expressed as mmol $\mathrm{g}^{-1}$ fresh mass.

Similarly, a separate batch of fresh and deteriorated seeds was hydrated in the range of solutions described above and the content of 4-HNE was estimated at about the end of phase II of hydration. Seeds $(1 \mathrm{~g})$ were homogenized in $5 \mathrm{~mL}$ of cold borate buffer $(0.2 \mathrm{M}, \mathrm{pH} 7.4)$ at $4{ }^{\circ} \mathrm{C}$. The homogenate was then mixed with $10 \%(w / v)$ TCA and centrifuged at $12,000 \times g$ for $15 \mathrm{~min}$. The supernatant obtained was thoroughly mixed with 2, 4-dinitrophenyl hydrazine $\left(1 \mathrm{mg} \mathrm{mL}^{-1}\right.$ in $\left.0.5 \mathrm{M} \mathrm{HCl}\right)$. The complex obtained was kept at laboratory conditions for $2 \mathrm{~h}$ after which it was extracted in hexane and evaporated under liquid nitrogen. The residue was dissolved in methanol and absorbance was read at $350 \mathrm{~nm}$ against methanol as blank [31]. Content of 4-HNE in the samples was expressed as mmol $\mathrm{g}^{-1}$ fresh mass.

\subsection{Determination of Seeds Membrane Stability Index}

Membrane stability index of the seeds was assessed using the method of [32]. MilliQ water (MW) (Millipore, Gradient A-10, Burlington, MA, USA) $(20 \mathrm{~mL})$ was added to two test tubes and seeds $(1 \mathrm{~g})$ were added to each tube. One tube was placed in a water bath at $40{ }^{\circ} \mathrm{C}$ for $40 \mathrm{~min}$ (T1) and the other in a water bath at $100{ }^{\circ} \mathrm{C}$ for $15 \mathrm{~min}$ (T2). Electrical conductance of the water in both test tubes after incubation was measured with a multi-cell electrical conductivity meter (Reid and Associates, Durban, South Africa). The measurement was repeated four times and the average of the four trials was reported as the electrical conductance and used in calculating the membrane stability index (MSI) of the seeds; MSI $=[1-(\mathrm{T} 1 / \mathrm{T} 2)] \times 100$.

\subsection{Statistical Analysis}

The data collected were subjected to analysis of variance (ANOVA) using GenStat Release 12.1 (PC/Windows Vista) (VSN International Ltd., Hemel Hempstead, UK, 2009). Means of the treatments were compared using the Tukey test at $5 \%$ least significant difference $\left(\mathrm{LSD}_{0.05}\right)$.

\section{Results}

\subsection{Effect of Cathodic Water on Seedling Emergence}

Seedling emergence was delayed as a result of controlled deterioration of seeds in all the test species. Emergence was delayed for about $2 \mathrm{~d}$ in E. caffra and B. speciosus and $3 \mathrm{~d}$ in C. erythrophyllum (Table 1). Total seedling emergence, mean emergence time, emergence index and uniformity of emergence were also adversely affected by controlled 
deterioration when compared with the fresh unprimed seeds. Priming deteriorated seeds promoted earlier and more uniform emergence when compared with the control. While for B. speciosus the effects were mostly significant for cathodic water, the other priming solutions had smaller effects that were often not significant. In C. erythrophyllum, while priming tended to improve emergence, the effects were mostly not significant. In contrast, priming fresh seeds only resulted in small increases in total emergence in all species.

\subsection{Effect of Priming on Seedling Growth}

Priming fresh seeds with all solutions tended to increased growth parameters (Tables 2 and 3). In general, cathodic water was most effective, although the differences between cathodic water and the other solutions were not always significant. The increases in total dry mass were significant for all priming solutions for B. speciosus and C. erythrophyllum, but only for cathodic water for E. caffra. Controlled deterioration of seeds significantly reduced the subsequent growth of plants derived from the deteriorated seeds. For example, root length was typically reduced by c. $50 \%$ (Table 2). The numbers of leaves were reduced by $23 \%$ in C. erythrophyllum, $35 \%$ in B speciosus and $43 \%$ in E. caffra (Table 2). The biomasses of the individual plant parts and the total biomasses of all species were very significantly reduced in seedlings derived from deteriorated seeds (Table 3). Invigorating deteriorated seeds with any of the priming solutions greatly increased the growth parameters of all species. Most of the improvements were significant for the seeds primed with cathodic water, while the improvement in the seeds primed with $\mathrm{CaMg}$ solution and deionized water treatments were smaller and not always significant (Table 3 ). In some cases, the parameters were more than double compared with plants derived from unprimed aged seeds.

\subsection{Effect of Priming on Photosynthetic Parameters}

For all species, seedlings derived from deteriorated rather than fresh seeds had significantly lower chlorophyll contents, photochemical efficiencies and rates of photosynthesis and transpiration (Figures 1 and 2). While having little effect on fresh seeds, priming tended to increase these parameters in deteriorated seeds. In B. speciosus, cathodic water significantly improved these parameters, while the effects of the other priming solutions tended to be less and were not always significant. In the other two species, the effects of priming were smaller and usually not significant, although in general, cathodic water gave the best results. 


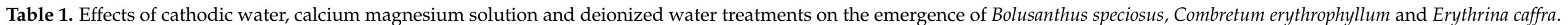

\begin{tabular}{|c|c|c|c|c|c|c|c|c|c|c|}
\hline Emergence & & FSC & FSP.CW & FSP.CM & FSP.DW & ASC & ASP.CW & ASP.CM & ASP.DW & LSD \\
\hline First day of emergence & & $6.0 \pm 0.8 \mathrm{abc}$ & $4.5 \pm 0.5^{\mathrm{a}}$ & $5.0 \pm 0.6^{\mathrm{ab}}$ & $7.0 \pm 0.6^{\mathrm{abcd}}$ & $9.5 \pm 1.0^{\mathrm{d}}$ & $7.0 \pm 1.0^{\mathrm{abcd}}$ & $8.0 \pm 0.8 \mathrm{bcd}$ & $8.5 \pm 0.5^{\mathrm{cd}}$ & $2.2 \pm 1.05$ \\
\hline Emergence $\%$ & है & $85.0 \pm 5.0^{\mathrm{cd}}$ & $100.0 \pm 0.0^{\mathrm{d}}$ & $90.0 \pm 5.8^{d}$ & $90.0 \pm 5.8^{\mathrm{d}}$ & $30.0 \pm 5.8^{a}$ & $60.0 \pm 8.2^{b c}$ & $50.0 \pm 5.8 \mathrm{ab}$ & $50.0 \pm 5.8 \mathrm{ab}$ & $16.6 \pm 8.04$ \\
\hline Mean emergence time & \& & $3.3 \pm 0.1^{c}$ & $4.6 \pm 0.041^{\mathrm{d}}$ & $3.6 \pm 0.2^{c}$ & $3.3 \pm 0.2^{c}$ & $0.7 \pm 0.2^{\mathrm{a}}$ & $2.3 \pm 0.3^{\mathrm{b}}$ & $1.5 \pm 0.3^{\mathrm{ab}}$ & $1.6 \pm 0.2^{\mathrm{ab}}$ & $0.6 \pm 0.30$ \\
\hline Emergence index & के & $1.6 \pm 0.1^{\mathrm{d}}$ & $2.6 \pm 0.1^{\mathrm{e}}$ & $1.7 \pm 0.2^{\mathrm{d}}$ & $1.4 \pm 0.1 \mathrm{~cd}$ & $0.3 \pm 0.1^{\mathrm{a}}$ & $1.0 \pm 0.1^{\mathrm{bc}}$ & $0.6 \pm 0.1 \mathrm{ab}$ & $0.6 \pm 0.1$ ab & $0.3 \pm 0.16$ \\
\hline Uniformity of emergence & & $0.023 \pm 0.001 \mathrm{~d}$ & $0.037 \pm 0.001^{\mathrm{e}}$ & $0.024 \pm 0.001^{\mathrm{d}}$ & $0.021 \pm 0.002^{\mathrm{cd}}$ & $0.010 \pm 0.001^{\mathrm{a}}$ & $0.016 \pm 0.001 \mathrm{bc}$ & $0.012 \pm 0.002^{\mathrm{ab}}$ & $0.012 \pm 0.001 \mathrm{ab}$ & $0.004 \pm 0.002$ \\
\hline First day of emergence & $\equiv$ & $12.5 \pm 0.5^{\mathrm{a}}$ & $11.5 \pm 0.3^{\mathrm{a}}$ & $12.8 \pm 0.6^{\mathrm{a}}$ & $11.8 \pm 0.5^{\mathrm{a}}$ & $15.8 \pm 1.1^{\mathrm{b}}$ & $13.0 \pm 0.6^{\mathrm{ab}}$ & $13.0 \pm 0.4^{\mathrm{ab}}$ & $12.8 \pm 0.6^{\mathrm{a}}$ & $1.8 \pm 0.88$ \\
\hline Emergence $\%$ & 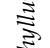 & $60.0 \pm 8.2^{b c}$ & $70.0 \pm 5.8^{c}$ & $60.0 \pm 8.2^{b c}$ & $45.0 \pm 9.6 \mathrm{abc}$ & $25.0 \pm 5.0^{\mathrm{a}}$ & $45.0 \pm 5.0 \mathrm{abc}$ & $35.0 \pm 5.0 \mathrm{ab}$ & $30.0 \pm 5.8^{\mathrm{ab}}$ & $19.6 \pm 9.57$ \\
\hline Mean emergence time & $\frac{5}{2}$ & $2.3 \pm 0.3^{\mathrm{bc}}$ & $2.8 \pm 0.3^{c}$ & $2.5 \pm 0.4^{\mathrm{bc}}$ & $1.9 \pm 0.5^{\mathrm{abc}}$ & $0.7 \pm 0.229^{a}$ & $1.5 \pm 0.2^{\mathrm{abc}}$ & $1.3 \pm 0.2^{\mathrm{abc}}$ & $1.2 \pm 0.3 \mathrm{ab}$ & $0.9 \pm 0.43$ \\
\hline Emergence index & $\frac{7}{2}$ & $1.2 \pm 0.2^{\mathrm{bc}}$ & $1.5 \pm 0.2^{\mathrm{c}}$ & $1.3 \pm 0.2 \mathrm{bc}$ & $1.1 \pm 0.3^{\mathrm{abc}}$ & $0.3 \pm 0.111^{\mathrm{a}}$ & $0.7 \pm 0.095 \mathrm{abc}$ & $0.7 \pm 0.128 \mathrm{abc}$ & $0.6 \pm 0.144 \mathrm{ab}$ & $0.5 \pm 0.25$ \\
\hline First day of emergence & & $5.3 \pm 0.3^{\mathrm{ab}}$ & $4.5 \pm 0.3^{\mathrm{a}}$ & $4.8 \pm 0.3 \mathrm{ab}$ & $4.8 \pm 0.3 \mathrm{ab}$ & $6.8 \pm 0.3^{c}$ & $5.8 \pm 0.3 \mathrm{bc}$ & $6.5 \pm 0.3^{c}$ & $6.8 \pm 0.3^{c}$ & $0.8 \pm 0.37$ \\
\hline Emergence $\%$ & $\Xi$ & $100.0 \pm 0.0^{\mathrm{b}}$ & $100.0 \pm 0.0^{\mathrm{b}}$ & $100.0 \pm 0.0^{\mathrm{b}}$ & $100.0 \pm 0.0^{\mathrm{b}}$ & $40.0 \pm 0.0^{\mathrm{a}}$ & $50.0 \pm 5.8^{a}$ & $45.0 \pm 5.0^{a}$ & $50.0 \pm 5.8^{a}$ & $9.9 \pm 4.79$ \\
\hline Mean emergence time & 害 & $3.6 \pm 0.1^{b}$ & $4.6 \pm 0.1^{\mathrm{c}}$ & $4.2 \pm 0.2 \mathrm{bc}$ & $4.1 \pm 0.1^{\mathrm{bc}}$ & $1.0 \pm 0.074^{\mathrm{a}}$ & $1.5 \pm 0.1^{\mathrm{a}}$ & $1.4 \pm 0.2^{\mathrm{a}}$ & $1.3 \pm 0.2^{\mathrm{a}}$ & $0.4 \pm 019$ \\
\hline Emergence index & 8 & $2.5 \pm 0.1^{\mathrm{b}}$ & $4.1 \pm 0.2^{\mathrm{d}}$ & $3.3 \pm 0.3^{c}$ & $3.2 \pm 0.2 \mathrm{bc}$ & $0.6 \pm 0.060^{\mathrm{a}}$ & $1.0 \pm 0.092^{a}$ & $0.9 \pm 0.139^{a}$ & $0.8 \pm 0.119^{a}$ & $0.4 \pm 0.22$ \\
\hline Uniformity of emergence & $\omega$ & $0.059 \pm 0.004^{b}$ & $0.136 \pm 0.012^{\mathrm{d}}$ & $0.095 \pm 0.013^{c}$ & $0.086 \pm 0.007 \mathrm{bc}$ & $0.020 \pm 0.001^{\mathrm{a}}$ & $0.025 \pm 0.001^{\mathrm{a}}$ & $0.023 \pm 0.002^{\mathrm{a}}$ & $0.022 \pm 0.002^{\mathrm{a}}$ & $0.02 \pm 0.01$ \\
\hline
\end{tabular}

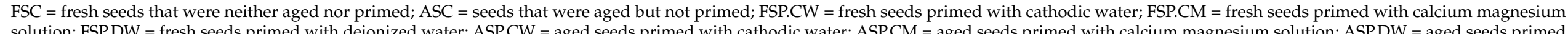

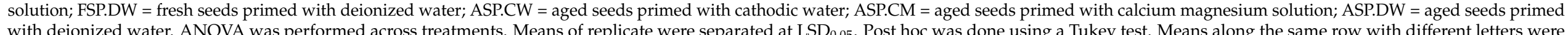

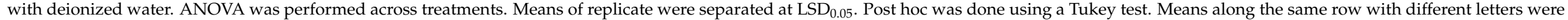
significantly different $(p<0.05, n=32)$.

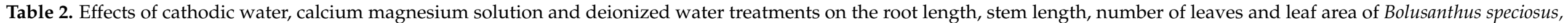
Combretum erythrophyllum and Erythrina caffra.

\begin{tabular}{|c|c|c|c|c|c|c|c|c|c|c|c|c|}
\hline \multirow[b]{2}{*}{ Treatment } & \multicolumn{4}{|c|}{ Bolusanthus speciosus } & \multicolumn{4}{|c|}{ Combretum erythrophyllum } & \multicolumn{4}{|c|}{ Erythrina caffra } \\
\hline & $\begin{array}{l}\text { Root Length } \\
\text { (cm) }\end{array}$ & $\begin{array}{l}\text { Stem Length } \\
\text { (cm) }\end{array}$ & $\begin{array}{l}\text { Number of } \\
\text { Leaves }\end{array}$ & $\begin{array}{l}\text { Leaf Area } \\
\left(\mathrm{cm}^{2}\right)\end{array}$ & $\begin{array}{l}\text { Root Length } \\
\text { (cm) }\end{array}$ & $\begin{array}{l}\text { Stem Length } \\
\text { (cm) }\end{array}$ & $\begin{array}{l}\text { Number of } \\
\text { Leaves }(\mathrm{cm})\end{array}$ & $\begin{array}{l}\text { Leaf Area } \\
\left(\mathrm{cm}^{2}\right)\end{array}$ & $\begin{array}{l}\text { Root Length } \\
\text { (cm) }\end{array}$ & $\begin{array}{l}\text { Stem Length } \\
\text { (cm) }\end{array}$ & $\begin{array}{l}\text { Number of } \\
\text { Leaves }\end{array}$ & $\begin{array}{l}\text { Leaf Area } \\
\left(\mathrm{cm}^{2}\right)\end{array}$ \\
\hline FSC & $34.3 \pm 0.6^{d}$ & $13.0 \pm 0.8^{c}$ & $13.0 \pm 0.7^{b c}$ & $58.3 \pm 4.2^{b c}$ & $36.0 \pm 1.1^{\mathrm{bcd}}$ & $16.5 \pm 1.7^{c}$ & $15.0 \pm 1.1^{\mathrm{ab}}$ & $59.0 \pm 1.1^{\mathrm{d}}$ & $25.8 \pm 1.1^{c}$ & $17.5 \pm 1.0^{\text {cde }}$ & $12.8 \pm 0.5^{\mathrm{b}}$ & $716.2 \pm 15.4^{\mathrm{d}}$ \\
\hline FSP.CM & $33 \pm 0.7^{\mathrm{cd}}$ & $14.0 \pm 0.7^{c}$ & $12.0 \pm 0.4^{b c}$ & $72.6 \pm 4.2^{\mathrm{cd}}$ & $32.8 \pm 1.0^{b c}$ & $16.6 \pm 0.7^{c}$ & $16.5 \pm 0.6^{b}$ & $77.9 \pm 2.0^{\mathrm{f}}$ & $24.8 \pm 0.5^{c}$ & $17.0 \pm 0.7^{\mathrm{cd}}$ & $13.8 \pm 0.3^{b c}$ & $739.8 \pm 26.0^{\mathrm{d}}$ \\
\hline FSP.DW & $36.5 \pm 2^{d}$ & $14.3 \pm 0.2^{c}$ & $13.8 \pm 0.6^{\mathrm{cd}}$ & $74.1 \pm 2^{\mathrm{d}}$ & $36.3 \pm 1.4^{\mathrm{cd}}$ & $12.5 \pm 0.6^{b c}$ & $15.3 \pm 0.3^{\mathrm{ab}}$ & $69.3 \pm 1.4^{\mathrm{e}}$ & $30.5 \pm 1.0^{\mathrm{d}}$ & $19.3 \pm 0.6$ de & $15.0 \pm 0.4^{b c}$ & $736.2 \pm 14.6^{d}$ \\
\hline ASC & $18.3 \pm 1.1^{\mathrm{a}}$ & $7.5 \pm 0.2^{\mathrm{a}}$ & $8.5 \pm 0.6^{\mathrm{a}}$ & $21.2 \pm 1.3^{\mathrm{a}}$ & $18.5 \pm 0.6^{\mathrm{a}}$ & $7.2 \pm 0.2^{\mathrm{a}}$ & $11.5 \pm 0.6^{\mathrm{a}}$ & $20.5 \pm 0.5^{\mathrm{a}}$ & $11.9 \pm 0.9^{\mathrm{a}}$ & $9.9 \pm 0.4^{\mathrm{a}}$ & $7.3 \pm 0.5^{\mathrm{a}}$ & $86.3 \pm 0.6^{a}$ \\
\hline ASP.CW & $31.3 \pm 1.3^{\mathrm{bcd}}$ & $12.5 \pm 1.2^{c}$ & $11.5 \pm 0.6^{b c}$ & $58.0 \pm 1.8^{b c}$ & $30.8 \pm 0.5^{b}$ & $12.1 \pm 1.1 \mathrm{bc}$ & $14.3 \pm 0.8^{\mathrm{ab}}$ & $45.9 \pm 1.7^{\mathrm{c}}$ & $26.3 \pm 0.6^{c}$ & $14.3 \pm 0.5^{b c}$ & $13.5 \pm 0.6^{b}$ & $642.7 \pm 9.8^{c}$ \\
\hline ASP.CM & $28.5 \pm 1.2^{b c}$ & $9.0 \pm 0.9^{\mathrm{ab}}$ & $10.5 \pm 0.3^{\mathrm{ab}}$ & $31.0 \pm 2.1^{\mathrm{a}}$ & $21.9 \pm 2.2^{\mathrm{a}}$ & $11.4 \pm 0.7 \mathrm{ab}$ & $14.2 \pm 0.8^{\mathrm{ab}}$ & $27.0 \pm 1.7^{b}$ & $18.8 \pm 1.0^{\mathrm{b}}$ & $12.6 \pm 0.6^{\mathrm{ab}}$ & $8.5 \pm 0.6^{\mathrm{a}}$ & $122.7 \pm 1.2^{\mathrm{a}}$ \\
\hline $\mathrm{LSD}_{0.05}$ & $3.6 \pm 1.7$ & $2.0 \pm 1.0$ & $1.7 \pm 0.8$ & $9.3 \pm 4.5$ & $3.4 \pm 1.6$ & $2.9 \pm 1.4$ & $2.4 \pm 1.2$ & $4.0 \pm 2.0$ & $2.5 \pm 1.2$ & $2.3 \pm 1.1$ & $1.5 \pm 0.7$ & $43.9 \pm 21.3$ \\
\hline
\end{tabular}

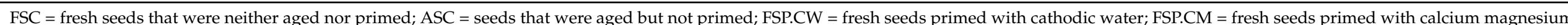

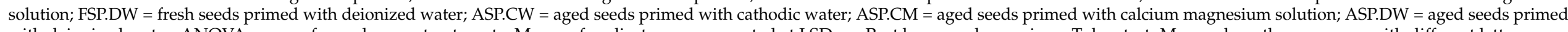

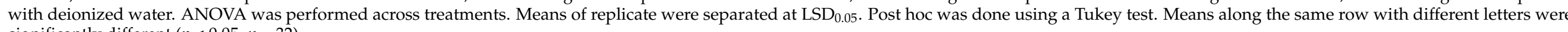
significantly different $(p<0.05, n=32)$. 


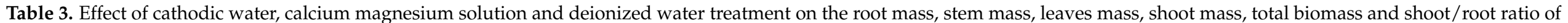
Bolusanthus speciosus, Combretum erythrophyllum and Erythrina caffra.

\begin{tabular}{|c|c|c|c|c|c|c|c|c|c|c|}
\hline Dry Mass (g Plant ${ }^{-1}$ ) & & FSC & FSP.CW & FSP.CM & FSP.DW & ASC & ASP.CW & ASP.CM & ASP.DW & $\mathrm{LSD}_{0.05}$ \\
\hline Root mass & & $0.12 \pm 0.004^{\mathrm{cd}}$ & $0.20 \pm 0.013^{\mathrm{e}}$ & $0.15 \pm 0.013^{\mathrm{de}}$ & $0.18 \pm 0.015^{\mathrm{e}}$ & $0.04 \pm 0.004^{\mathrm{a}}$ & $0.12 \pm 0.009 \mathrm{bcd}$ & $0.07 \pm 0.008^{a b}$ & $0.10 \pm 0.011 b c$ & $0.03 \pm 0.01$ \\
\hline Stem mass & $\underset{3}{3}$ & $0.13 \pm 0.008^{b}$ & $0.20 \pm 0.003^{c}$ & $0.13 \pm 0.004^{b}$ & $0.12 \pm 0.030^{b}$ & $0.05 \pm 0.001^{\mathrm{a}}$ & $0.11 \pm 0.004^{\mathrm{b}}$ & $0.09 \pm 0.002^{a b}$ & $0.10 \pm 0.002^{a b}$ & $0.03 \pm 0.02$ \\
\hline Leaf mass &.$\stackrel{0}{0}$ & $0.19 \pm 0.006^{b}$ & $0.28 \pm 0.016^{\mathrm{c}}$ & $0.31 \pm 0.007^{\mathrm{c}}$ & $0.30 \pm 0.036^{\mathrm{c}}$ & $0.10 \pm 0.004^{\mathrm{a}}$ & $0.19 \pm 0.007^{b}$ & $0.11 \pm 0.003^{a}$ & $0.16 \pm 0.006^{\mathrm{ab}}$ & $0.04 \pm 0.02$ \\
\hline Total biomass & $\infty$ & $0.45 \pm 0.014^{\mathrm{c}}$ & $0.68 \pm 0.023^{d}$ & $0.59 \pm 0.019^{d}$ & $0.59 \pm 0.068^{d}$ & $0.20 \pm 0.007^{\mathrm{a}}$ & $0.41 \pm 0.011^{\mathrm{c}}$ & $0.27 \pm 0.009 \mathrm{ab}$ & $0.37 \pm 0.012^{b c}$ & $0.08 \pm 0.04$ \\
\hline Shoot/root ratio & & $2.70 \pm 0.091^{\mathrm{a}}$ & $2.44 \pm 0.158^{a}$ & $2.93 \pm 0.198^{a}$ & $2.38 \pm 0.371^{\mathrm{a}}$ & $3.60 \pm 0.318^{a}$ & $2.60 \pm 0.260^{a}$ & $2.91 \pm 0.357^{\mathrm{a}}$ & $2.69 \pm 0.298^{\mathrm{a}}$ & $0.80 \pm 0.39$ \\
\hline Root mass & ह & $0.34 \pm 0.035^{\mathrm{c}}$ & $0.68 \pm 0.008^{e}$ & $0.53 \pm 0.018^{\mathrm{d}}$ & $0.33 \pm 0.031^{c}$ & $0.08 \pm 0.009^{a}$ & $0.25 \pm 0.012^{c}$ & $0.16 \pm 0.009 \mathrm{ab}$ & $0.16 \pm 0.004^{b}$ & $0.05 \pm 0.03$ \\
\hline Stem mass & $\underset{3}{\stackrel{3}{3}}$ & $0.20 \pm 0.025^{b}$ & $0.51 \pm 0.041^{\mathrm{d}}$ & $0.39 \pm 0.018^{c}$ & $0.25 \pm 0.019^{b}$ & $0.06 \pm 0.004^{\mathrm{a}}$ & $0.19 \pm 0.006^{b}$ & $0.09 \pm 0.006^{\mathrm{a}}$ & $0.05 \pm 0.003^{a}$ & $0.06 \pm 0.03$ \\
\hline Leaf mass & $\frac{\overrightarrow{2}}{2}$ & $0.35 \pm 0.018^{b}$ & $0.65 \pm 0.02^{c}$ & $0.65 \pm 0.016^{c}$ & $0.37 \pm 0.016^{b}$ & $0.067 \pm 0.004^{\mathrm{a}}$ & $0.29 \pm 0.032^{b}$ & $0.13 \pm 0.011^{\mathrm{a}}$ & $0.12 \pm 0.009^{a}$ & $0.05 \pm 0.02$ \\
\hline Shoot mass & $\stackrel{z}{5}$ & $0.55 \pm 0.027^{b c}$ & $1.16 \pm 0.036^{\mathrm{e}}$ & $1.04 \pm 0.022^{\mathrm{d}}$ & $0.62 \pm 0.015^{c}$ & $0.13 \pm 0.007^{\mathrm{a}}$ & $0.48 \pm 0.034^{b}$ & $0.23 \pm 0.016^{\mathrm{a}}$ & $0.18 \pm 0.008^{a}$ & $0.07 \pm 0.03$ \\
\hline Total biomass & \pm & $0.90 \pm 0.061^{\mathrm{cd}}$ & $1.84 \pm 0.043^{\mathrm{f}}$ & $1.57 \pm 0.036^{\mathrm{e}}$ & $0.96 \pm 0.039^{d}$ & $0.20 \pm 0.009^{a}$ & $0.74 \pm 0.025^{\mathrm{c}}$ & $0.38 \pm 0.025^{b}$ & $0.34 \pm 0.007^{a b}$ & $0.10 \pm 0.05$ \\
\hline Shoot/root ratio & $\dot{u}$ & $1.66 \pm 0.096^{\mathrm{ab}}$ & $1.70 \pm 0.037^{a b}$ & $1.95 \pm 0.048^{b}$ & $1.91 \pm 0.177^{b}$ & $1.74 \pm 0.328^{a b}$ & $1.93 \pm 0.224^{b}$ & $1.45 \pm 0.024 \mathrm{ab}$ & $1.07 \pm 0.070^{\mathrm{a}}$ & $0.47 \pm 0.23$ \\
\hline Root mass & & $0.87 \pm 0.106^{\mathrm{cd}}$ & $0.82 \pm 0.029 \mathrm{bcd}$ & $0.85 \pm 0.072^{\mathrm{cd}}$ & $1.08 \pm 0.153^{\mathrm{d}}$ & $0.26 \pm 0.025^{a}$ & $0.73 \pm 0.035^{b c d}$ & $0.55 \pm 0.085^{a b c}$ & $0.46 \pm 0.058^{a b}$ & $0.24 \pm 0.12$ \\
\hline Stem mass & & $1.06 \pm 0.074^{\mathrm{bcd}}$ & $1.56 \pm 0.149^{d}$ & $1.30 \pm 0.181^{\mathrm{cd}}$ & $1.37 \pm 0.144^{\mathrm{cd}}$ & $0.20 \pm 0.038^{a}$ & $0.93 \pm 0.170 \mathrm{bc}$ & $0.27 \pm 0.038^{\mathrm{a}}$ & $0.56 \pm 0.069^{a b}$ & $0.35 \pm 0.17$ \\
\hline Leaf mass & 卖 & $2.02 \pm 0.175 \mathrm{bc}$ & $3.31 \pm 0.202^{\mathrm{d}}$ & $2.26 \pm 0.163 \mathrm{bc}$ & $2.70 \pm 0.302^{\mathrm{cd}}$ & $0.21 \pm 0.041^{\mathrm{a}}$ & $1.46 \pm 0.247^{\mathrm{a}}$ & $0.42 \pm 0.064^{b}$ & $0.58 \pm 0.075^{\mathrm{a}}$ & $0.53 \pm 0.26$ \\
\hline Shoot mass & s. & $3.08 \pm 0.208^{b c}$ & $4.88 \pm 0.306^{\mathrm{d}}$ & $3.56 \pm 0.308^{b c}$ & $4.07 \pm 0.434^{\mathrm{cd}}$ & $0.41 \pm 0.068^{a}$ & $2.39 \pm 0.292^{b}$ & $0.69 \pm 0.101^{\mathrm{a}}$ & $1.15 \pm 0.140^{\mathrm{a}}$ & $0.76 \pm 0.37$ \\
\hline
\end{tabular}

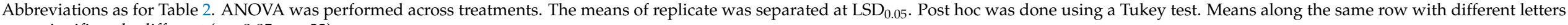
were significantly different $(p<0.05, n=32)$. 


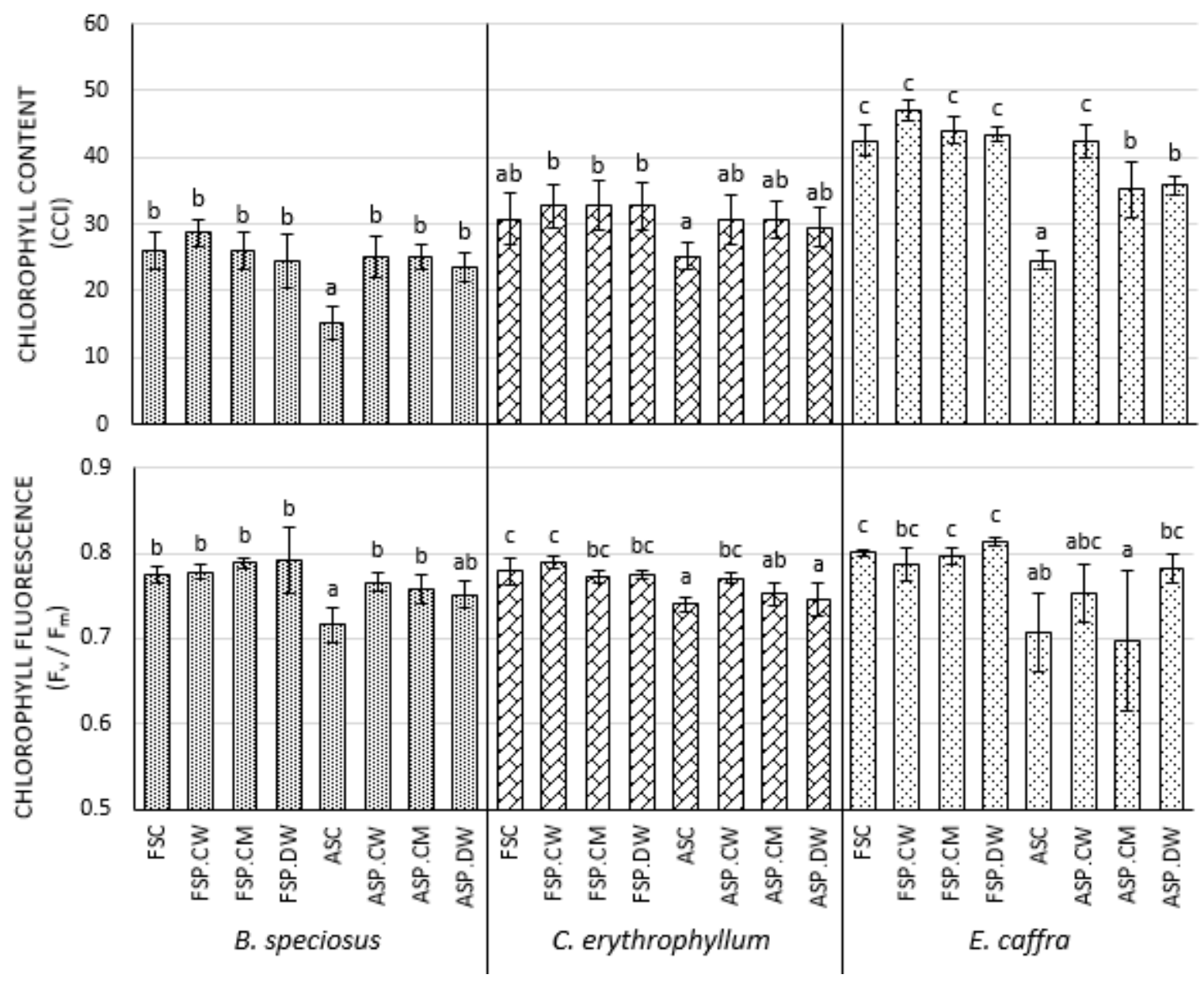

Figure 1. Effect of cathodic water, calcium magnesium solution and deionized water seed invigoration on the chlorophyll fluorescence and chlorophyll content in the leaves of Bolusanthus speciosus, Combretum erythrophyllum and Erythrina caffra. Bars with different letters in each species and for each parameter (chlorophyll content/ chlorophyll fluorescence) investigated are significantly different $(p<0.05)$. FSC $=$ fresh seeds that were neither aged nor primed; ASC $=$ seeds that were aged but not primed; FSP.CW = fresh seeds primed with cathodic water; FSP.CM = fresh seeds primed with calcium magnesium solution; FSP.DW $=$ fresh seeds primed with deionized water; ASP.CW $=$ aged seeds primed with cathodic water; ASP.CM $=$ aged seeds primed with calcium magnesium solution; ASP.DW = aged seeds primed with deionized water. 


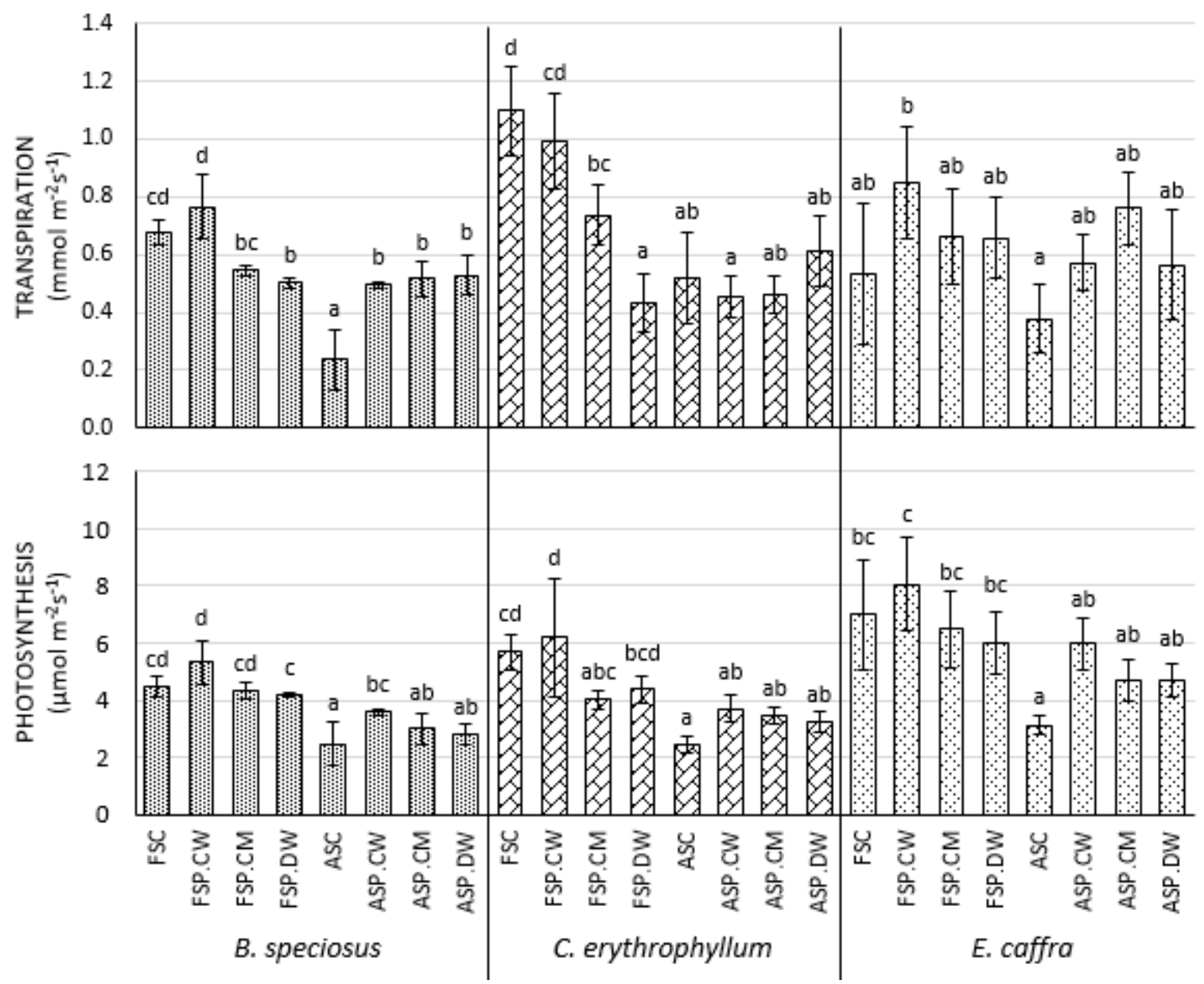

Figure 2. Effect of cathodic water, calcium magnesium solution and deionized water seed invigoration on the photosynthesis of Bolusanthus speciosus, Combretum erythrophyllum and Erythrina caffra. Bars with different letters in each species and for each parameter (photosynthesis/transpiration) investigated are significantly different $(p<0.05)$. Abbreviations as for Figure 1.

\subsection{Effect of Priming on Membrane Stability and the Levels of Oxidized Lipids}

In fresh seeds, priming tending to increase the MSI, significantly for cathodic water and distilled water in B. speciosus and for cathodic water in C. erythrophyllum. Primed fresh seeds had significantly lower MDA levels than unprimed seeds in B. speciosus and C. erythrophyllum, with cathodic water reducing MDA levels significantly more than the other priming solutions. E. caffra priming had no effect on MDA levels in fresh seeds. Priming fresh seeds with cathodic water significantly reduced 4-HNE in all species, but the other priming solutions had no significant effect. Controlled deterioration of the seeds of C. erythrophyllum and E. caffra significantly reduced their MSI compared with fresh seeds, but the reduction was smaller and not significant in B. speciosus (Figure 3). For all species, deterioration significantly increased the levels of the lipid oxidation products MDA and 4-HNE (Figure 4). The MSI of deteriorated seeds primed with all solutions had significantly better MSI than unprimed seeds, except in B. speciosus where only cathodic water had a significant effect (Figure 3). All priming solutions significantly reduced the amounts of lipid peroxidation product MDA in the seeds and cathodic water was significantly more effective than the other priming solutions for C. erythrophyllum and B. speciosus (Figure 4). However, priming only reduced 4-HNE levels in E. caffra and all solutions were equally effective. 


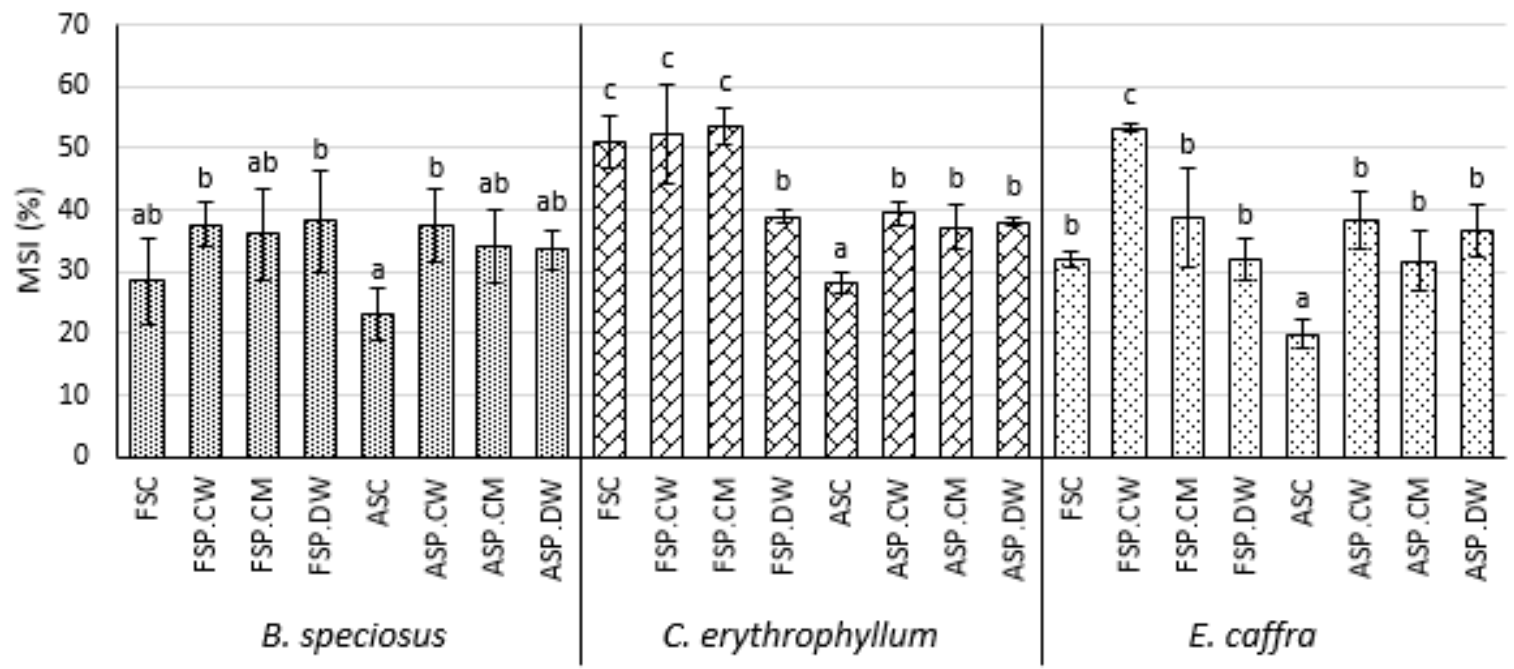

Figure 3. Effect of cathodic water, calcium magnesium solution and deionized water seed invigoration on the membrane stability index (MSI) of Bolusanthus speciosus, Combretum erythrophyllum and Erythrina caffra. Bars with different letters in each species are significantly different $(p<0.05)$. Abbreviations as for Figure 1.

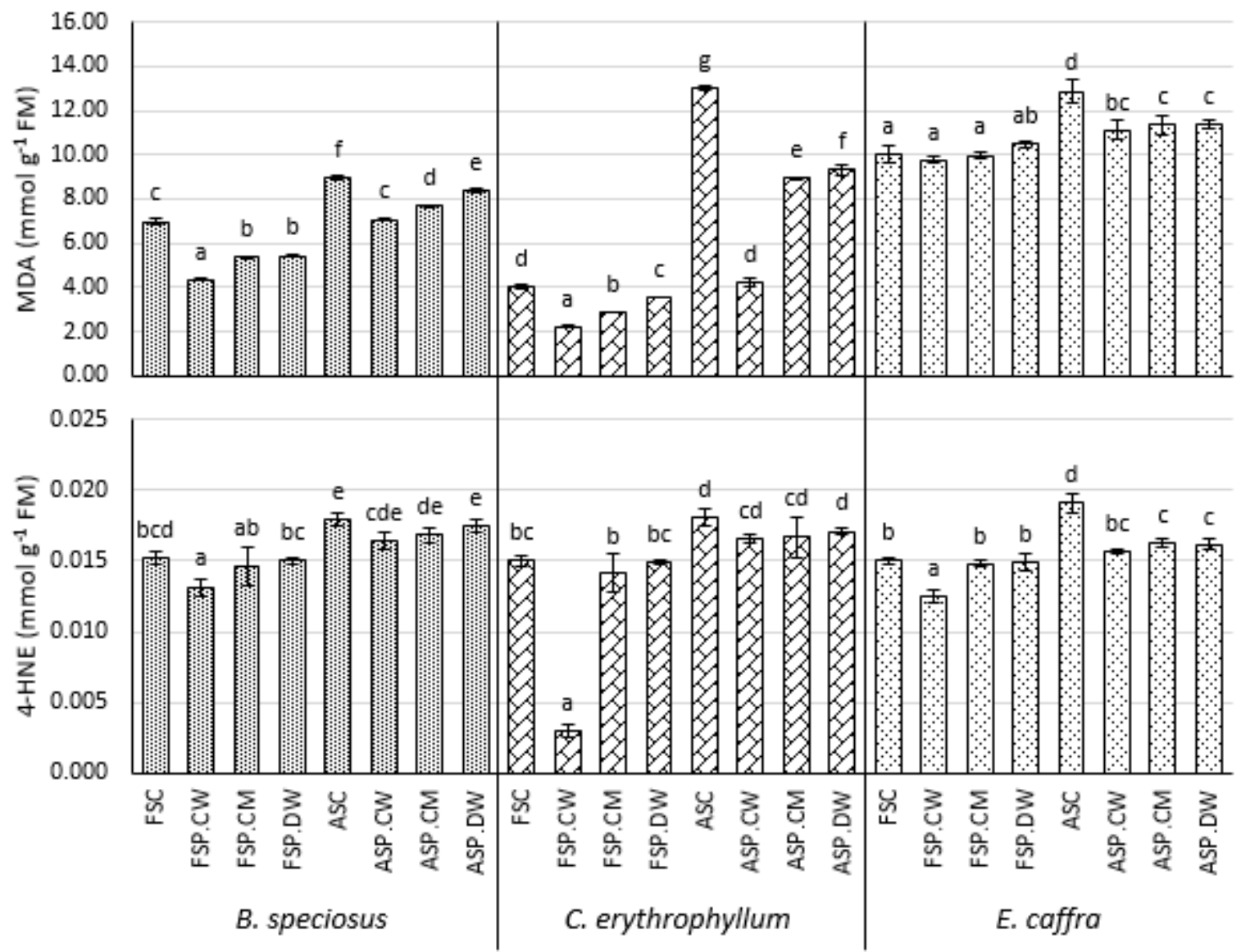

Figure 4. Effect of cathodic water, calcium magnesium solution and deionized water seed invigoration on MDA and 4-HNE contents in the seeds of Bolusanthus speciosus, Combretum erythrophyllum and Erythrina caffra. Bars with different letters in each species and for each parameter (MDA/4-HNE, 4-hydroxynonenal and malondialdehyde respectively) investigated are significantly different $(p<0.05)$. Abbreviations as for Figure 1. 


\section{Discussion}

The main conclusion of the work presented here is that for all three of the South African tree species tested, priming seeds with the strong reducing agent cathodic water significantly improved the growth of seedlings derived from deteriorated seeds. Furthermore, in one of the species, B. speciosus, the emergence of deteriorated orthodox seeds was also significantly increased by priming with cathodic water. While our earlier laboratory studies showed that cathodic water can improve the germination of deteriorated seeds [22,23], here we show that the benefits extend to emergence and the later stages of seedling development. The effects of cathodic water on the levels of lipid peroxidation products are generally consistent with the view that cathodic water acts by reducing the levels of ROS in aged seeds. We suggest that priming with cathodic water can be recommended as a useful tool to improve the conservation of orthodox seeds.

\subsection{Effects of Priming on Emergence}

In all species, controlled deterioration delayed seedling emergence and reduced the uniformity of emergence and the emergence index (Table 1). The first day of emergence was delayed by $3 \mathrm{~d}$ in C. erythrophyllum and about $2 \mathrm{~d}$ in E. caffra and B. speciosus In $B$. speciosus priming deteriorated seeds promoted earlier and more uniform emergence. The effects were mostly significant for cathodic water, while the other priming solutions had smaller effects that were often not significant. In the other two species, while priming tended to improve the emergence parameters, the effects were smaller and mostly not significant. Although the effects of cathodic water on emergence have not been tested before, priming with other solutions has been shown to improve emergence parameters. For example, priming was reported to promote the earlier emergence of seedlings in Oryza sativa [33] and Zea mays [34]. A particularly important emergence parameter is uniformity, because uniformity can improve stand establishment and increase biomass, particularly when conditions are suboptimal, such as during drought, salinity and water stress $[33,34]$. Uniformity of emergence can also reduce weed-inflicted yield loss, for example by up to $10 \%$ in rice [35]. While the improvements in emergence in C. erythrophyllum and E. caffra were too small to be significant, priming with cathodic water clearly significantly improves emergence in B. speciosus.

\subsection{Effect of Priming on Seedling Growth}

Priming fresh seeds with cathodic water and other solutions resulted in small, and in most cases not significant, increases in the growth of the resulting seedlings (Tables 2 and 3). The small improvements that occurred may be due to the repair of the natural deterioration that occurred before harvesting and during seed storage [36,37]. Seedlings derived from seeds subjected to controlled deterioration displayed significantly reduced growth (Tables 2 and 3). Invigoration of deteriorated seeds with all priming solutions in water resulted in better seedling growth for all species (Tables 2 and 3). Most of the improvements were significant for the seeds primed with cathodic water, while the improvement in the seeds primed with the other priming solutions were smaller and often not significant. Interestingly, while priming only improved emergence in one of the species tested here (B. speciosus, Table 1), cathodic water significantly improved the growth parameters of seedlings derived from deteriorated seeds in all species tested here. The improvement in seedling growth in plants derived from primed seeds may have occurred due to increases in the activities of enzymes such as $\alpha$-amylase. Such increases in enzymatic activities have been reported to promote the hydrolysis of starch into soluble sugars for seed respiration and better growth [22]. While seed priming is known to promote seedling growth (for review see [38]), cathodic water is clearly more effective that the other solutions tested here. 


\subsection{Effects of Priming on Photosynthetic Parameters}

One of the ways that priming improves seedling growth is by improving photosynthesis. In all species, seed deterioration significantly reduced the chlorophyll contents, photochemical efficiencies and rates of photosynthesis and transpiration in the resulting seedlings (Figures 1 and 2). While having little effect on fresh seeds, priming tended to increase these parameters in deteriorated seeds. In B. speciosus, all effects of cathodic water were significant, while the effects of the other priming solutions tended to be less and were not always significant. In the other two species, the effects of priming were smaller and usually not significant, although in general, cathodic water gave the best results. Although not tested for cathodic water, priming with other solutions is well known to improve photosynthesis in the resulting seedlings [39] (for review see [38]). Theoretically, priming may have increased the capacity for photosynthetic electron transport, or possibly a greater investment in enzymes of the Calvin cycle [40]. While we did not study the mechanisms of the improvement in photosynthesis in detail, the net result of the general improvements in photosynthesis was an increase in plant growth (Tables 2 and 3)

\subsection{Effects on Membrane Leakage and Lipid Peroxidation Products}

The effects of priming on membrane leakage and lipid peroxidation, particularly with cathodic water, are generally consistent with priming reducing oxidative stress in the seeds of the three species tested here. As discussed in the Introduction, a gradual increase in oxidative stress is considered to be a major reason for the deterioration of seeds during aging. Controlled deterioration significantly reduced the MSI of $C$. erythrophyllum and E. caffra, but not B. speciosus (Figure 3). For all species, deterioration significantly increased the levels of the lipid oxidation products MDA and 4-HNE (Figure 4). All priming solutions significantly increased the MSI, except in B. speciosus where only cathodic water had a significant effect (Figure 3). All priming solutions significantly reduced the amounts of lipid peroxidation product MDA in the seeds and cathodic water was significantly more effective than the other priming solutions for C. erythrophyllum and E. caffra (Figure 4). The greater efficacy of cathodic water may be linked to its strong antioxidant property. However, priming only reduced levels of the other oxidation product we tested, 4-HNE, in E. caffra and all solutions were equally effective. Lipid oxidation and MSI are intimately linked, as lipid oxidation is well known to increase membrane permeability [41]. Membrane permeability leads to leakage of solute from the cells leading to loss of critical nutrients such as sugar and amino acids and consequently reduced growth. The differences observed among the species in regards to the impact of controlled deterioration as evidenced in the changes that occurred in MDA, 4-HNE and MSI essentially may be due to differences in species biology (not investigated in this study).

There have been numerous studies that have shown that priming reduces oxidative stress in seeds (for review see [42]). It is possible that priming upregulates ROS scavenging enzymes in the seeds. For example, References $[43,44]$ report that priming seeds of Spinacia oleracea upregulates APX, SOD, CAT and GR. Reference [45] showed that during the aging of Helianthus annuus seeds, $\mathrm{H}_{2} \mathrm{O}_{2}$ accumulated and the expression of CAT was reduced. Priming both invigorated the seeds and increased the expression and activity of CAT. Alternatively, or perhaps additionally, the priming-induced reductions in lipid oxidation products and increases in MSI may have been because priming more generally reduced ROS formation [46]. In the present study, cathodic water may have directly reacted with ROS. Recently, Reference [47] showed that treating excised embryonic axes from the recalcitrant seeds of the South African tree Ekebergia capensis with cathodic water both improved survival of the explants following cryopreservation and also reduced the formation of ROS. However, as other priming solutions were also beneficial, in addition to direct reactions with ROS, cathodic water may have reduced ROS levels in other ways e.g., by improving the activity of ROS-scavenging enzymes. The precise mechanisms whereby priming increased MSI and reduced lipid peroxidation were not investigated in the present study. While priming with all solutions reduced oxidative stress and improved 
the MSI, cathodic water tended to have a slighter stronger ameliorative effect, particularly in its ability to reduce MDA formation (Figure 4). This may explain why the strongly reducing cathodic water was better overall at improving the growth of seedlings derived from deteriorated seeds.

\section{Conclusions}

Our original motivation for testing the effectiveness of cathodic water in germplasm conservation came from an earlier study, in which the deterioration of maize seed was counteracted by cathodic protection [48]. In that study, maize seeds were placed on an aluminum foil disc with the disc attached to the cathode of a power pack [48,49]. However, a solution of cathodic water is more practical to use than foil discs and in later experiments we showed that cathodic water can improve the cryopreservation of the embryonic axes and embryos of recalcitrant seeds [21,47,50] and shoot tips [51], and could improve the germination of orthodox seeds [22,23]. In the work presented here we showed that cathodic water is a particularly effective priming agent for improving the emergence and subsequent seedling growth of deteriorated seeds. While all priming solutions were capable of some measure of invigoration, priming with cathodic water was most effective. Results from measuring membrane leakage and lipid oxidation in primed seeds are generally consistent with the view that the benefits of cathodic water derive from its ability to reduce oxidative stress, probably at least in part because of its strong antioxidant capacity. The deterioration of seeds in seed banks is of global concern, as it affects the long-term conservation of genetic diversity of both wild species and agricultural plants [52] essential for future breeding programs. In the future, it will be necessary to produce varieties that perform well under future climate change scenarios, particularly in sub-Saharan Africa where the effects of climate change are likely to be severe $[53,54]$. Results presented here show that priming deteriorated seeds with cathodic water can be an effective means of improving orthodox seed conservation.

Author Contributions: Conceptualization, N.W.P.; investigation, K.F.; Writing, K.F., R.P.B. and B.V. All authors have read and agreed to the published version of the manuscript.

Funding: National Research Foundation of South Africa grant to NW Pammenter (grant number CPRR13092145823 entitled "Cathodic quenching of oxidative stress in explants processed for cryostorage and in vitro procedures"). This study was partially funded by the University of KwaZulu-Natal, South Africa. R Beckett thanks the Russian Government Program of Competitive Growth of Kazan Federal University for partial financial support.

Institutional Review Board Statement: Not applicable.

Informed Consent Statement: Not applicable.

Data Availability Statement: Data is contained within the article.

Conflicts of Interest: The authors declare no conflict of interest. The funders had no role in the design of the study; in the collection, analyses, or interpretation of data; in the writing of the manuscript, or in the decision to publish the results.

\section{References}

1. Farooq, M.; Usman, M.; Nadeem, F.; Rehman, H.U.; Wahid, A.; Basra, S.M.A.; Siddique, K.H.M. Seed priming in field crops: Potential benefits, adoption and challenges. Crop. Pasture Sci. 2019, 70, 731-771. [CrossRef]

2. Sreepriya, S.; Girija, T. Seed invigoration- a technique for improving vigour and productivity of sesame (Sesamum indicum L.) variety Thilak. J. Trop. Agric. 2019, 57, 10.

3. Sahu, B.; Sahu, A.K.; Thomas, V.; Naithani, S.C. Reactive oxygen species, lipid peroxidation, protein oxidation and anti-oxidative enzymes in dehydrating Karanj (Pongamia pinnata) seeds during storage. S. Afr. J. Bot. 2017, 112, 383-390. [CrossRef]

4. Barrera, G.; Pizzimenti, S.; Daga, M.; Dianzani, C.; Arcaro, A.; Cetrangolo, G.P.; Giordano, G.; Cucci, M.A.; Graf, M.; Gentile, F. Lipid Peroxidation-Derived Aldehydes, 4-Hydroxynonenal and Malondialdehyde in Aging-Related Disorders. Antioxidants 2018, 7, 102. [CrossRef] [PubMed]

5. Berjak, P.; Pammenter, N.W. From Avicennia to Zizania: Seed Recalcitrance in Perspective. Ann. Bot. 2007, 101, 213-228. [CrossRef] [PubMed] 
6. Ardebili, Z.M.; Abbaspour, H.; Afshari, R.T.; Kalat, S.M.N. Evaluation of Germination and Antioxidant Activity in GA3-Primed Deteriorated Wheat Seed. Russ. J. Plant Physiol. 2019, 66, 958-965. [CrossRef]

7. Smith, M.T.; Berjak, P. Deteriorative changes associated with the loss of viability of stored desiccation tolerant and desiccation sensitive seeds. In Seed Development and Germination; Kigel, J., Galili, G., Eds.; Marcel Dekker: New York, NY, USA, 1995; pp. 701-746.

8. Finchsavage, W.E.; Bassel, G.W. Seed vigour and crop establishment: Extending performance beyond adaptation. J. Exp. Bot. 2016, 67, 567-591. [CrossRef] [PubMed]

9. Taylor, A.G.; Allen, P.S.; Bennett, M.A.; Bradford, K.J.; Burris, J.S.; Misra, M.K. Seed enhancements. Seed Sci. Res. 1998, 8, $245-256$. [CrossRef]

10. Basra, S.; Afzal, I.; Anwar, S.; Anwar-ul-Haq, M.; Shafiq, M.; Majeed, K. Alleviation of salinity stress by seed invigoration techniques in wheat (Triticum aestivum). Seed Sci. Technol. 2006, 28, 36-46.

11. Farooq, M.; Basra, S.M.A.; Ahmad, N.; Hafeez, K. Thermal Hardening: A New Seed Vigor Enhancement Tool in Rice. J. Integr. Plant Biol. 2005, 47, 187-193. [CrossRef]

12. Farooq, M.; Basra, S.M.A.; Ahmad, N. Improving the performance of transplanted rice by seed priming. Plant Growth Regul. 2007, 51, 129-137. [CrossRef]

13. Song, W.J.; Hu, J.; Qiu, J.; Geng, H.Y.; Wang, R.M. Primary study on the development of special seed coating agents and their application in rice (Oryza saliva L.) cultivated by direct seeding. J. Zhejiang Univ. 2005, 31, 368-373.

14. Ella, E.S.; Dionisio-Sese, M.L.; Ismail, A.M. Seed pre-treatment in rice reduces damage, enhances carbohydrate mobilization and improves emergence and seedling establishment under flooded conditions. AoB PLANTS 2011, 2011, plr007. [CrossRef] [PubMed]

15. Heydecker, W.; Coolbear, P. Seed treatments for improved performance-survey and attempted prognosis. Seed Sci. Technol. 1977, 5, 353-425.

16. McDonald, M.B. Seed priming. In Seed Technology and Its Biological Basis; Black, M., Bewley, J.D., Eds.; Sheffield Academic Press: Sheffield, UK, 2000; pp. 287-325.

17. McDonald, M.B. Orthodox seed deterioration and its repair. In Handbook of Seed Physiology: Applications to Agriculture; BenechArnold, R.L., Sanchez, R.A., Eds.; Food Products Press: New York, NY, USA, 2004; pp. 273-304.

18. Eskandari, H.; Kazemi, K. Effect of Seed Priming on Germination Properties and Seedling Establishment of Cowpea (Vigna sinensis). Not. Sci. Biol. 2011, 3, 113-116. [CrossRef]

19. Farooq, M.; Basra, S.M.A.; Rehman, H.; Saleem, B.A. Seed Priming Enhances the Performance of Late Sown Wheat (Triticum aestivum L.) by Improving Chilling Tolerance. J. Agron. Crop. Sci. 2008, 194, 55-60. [CrossRef]

20. Arun, M.; Hebbar, S.S.; Bhanuprakas, K.; Senthivel, T. Seed priming improves irrigation water use efficiency, yield and yield components of summer cowpea under limited water conditions. Legum. Res. Int. J. 2017, 40, 864-871. [CrossRef]

21. Berjak, P.; Sershen; Varghese, B.; Pammenter, N. Cathodic amelioration of the adverse effects of oxidative stress accompanying procedures necessary for cryopreservation of embryonic axes of recalcitrant-seeded species. Seed Sci. Res. 2011, 21, 187-203. [CrossRef]

22. Fatokun, K.; Beckett, R.P.; Varghese, B.; Pammenter, N.W. Germination indices of orthodox seeds as influ-enced by controlled deterioration and cathodic water seed invigoration. J. Environ. Biol. 2020, 41, 1105-1111. [CrossRef]

23. Gondwe, D.; Berjak, P.; Pammenter, N.; Sershen; Varghese, B. Effect of priming with cathodic water and subsequent storage on invigoration of Pisum sativum, Cucurbita maxima and Lycopersicon esculentum seeds. Seed Sci. Technol. 2016, 44, 370-381. [CrossRef]

24. Bewley, J.D.; Black, M. Seeds Physiology of Development and Germination (The Language of Science); Plenum Press: New York, NY, USA, 1994; p. 230.

25. Bhattacharya, S.; Guha, P.; Mandal, A.K. Deteriorative changes in enzyme activity of non-invigorated and invigorated soybean seeds (Glycine max [L.] Merrill, cv. Soyamax). Legum. Res. Int. J. 2018, 42, 633-639. [CrossRef]

26. Mycock, D.J. Addition of calcium and magnesium to a glycerol and sucrose cryoprotectant solution improves the quality of plant embryo recovery from cryostorage. Cryo Lett. 1999, 20, 77-82.

27. Ellis, R.A.; Roberts, E.R. The quantification of ageing and survival in orthodox seeds. Seed Sci. Technol. 1981, 9, $373-409$.

28. Czabator, F.J. Germination value: An index combining speed and completeness of pine seed germination. For. Sci. 1962, 8, 386-396.

29. Abdollahi, M.; Eshghi, S.; Tafazzoli, E.; Moosavi, N. Effects of paclobutrazol, boric acid and zinc sulfate on vegetative and reproductive growth of strawberry cv. Selva. J. Agric. Sci. Technol. 2012, 14, 357-363.

30. Hodges, D.M.; Delong, J.M.; Forney, C.F.; Prange, R.K. Improving the thiobarbituric acid-reactive-substances assay for estimating lipid peroxidation in plant tissues containing anthocyanin and other interfering compounds. Planta 1999, 207, 604-611. [CrossRef]

31. Ray, S.; Roy, K.; Sengupta, C. Evaluation of protective effects of water extract of Spirulina platensis on cisplatin-induced lipid peroxidation. Indian J. Pharm. Sci. 2007, 69, 378-383.

32. Yuan, L.; Zhu, S.; Li, S.; Shu, S.; Sun, J.; Guo, S. 24-Epibrassinolide regulates carbohydrate metabolism and increases polyamine content in cucumber exposed to $\left.\mathrm{Ca} \mathrm{NO}_{3}\right)_{2}$ stress. Acta Physiol. Plant. 2014, 36, 2845-2852. [CrossRef]

33. Wang, W.; He, A.; Peng, S.; Huang, J.; Cui, K.; Nie, L. The Effect of Storage Condition and Duration on the Deterioration of Primed Rice Seeds. Front. Plant Sci. 2018, 9, 172. [CrossRef] 
34. Ghassemi-Golezani, K.; Farshbaf-Jafari, S.; Shafagh-Kolvanagh, J. Seed Priming and Field Performance of Soybean (Glycine max L.) in Response to Water Limitation. Not. Bot. Horti Agrobot. Cluj-Napoca 2011, 39, 186-189. [CrossRef]

35. Farooq, M.; Basra, S.; Khalid, M.; Tabassum, R.; Mahmood, T. Nutrient homeostasis, metabolism of reserves, and seedling vigor as affected by seed priming in coarse rice. Can. J. Bot. 2006, 84, 1196-1202. [CrossRef]

36. Andreev, I.O.; Spiridonova, E.V.; Kunakh, V.A.; Solov'Yan, V.T. Aging and Loss of Germination in Rye Seeds Is Accompanied by a Decreased Fragmentation of Nuclear DNA at Loop Domain Boundaries. Russ. J. Plant Physiol. 2004, 51, 241-248. [CrossRef]

37. Kranner, I.; Chen, H.; Birtiæ, S.; Pritchard, H. Mechanisms of viability loss in dry orthodox seeds and during imbibition. S. Afr. J. Bot. 2007, 73, 489. [CrossRef]

38. Pawar, V.A.; Laware, S.L. Seed priming: A critical review. Int. J. Sci. Res. Biol. Sci. 2018, 31, 94-101. [CrossRef]

39. Anwar, A.; Xianchang, Y.U.; Yansu, L.I. Seed priming as a promising technique to improve growth, chlorophyll, photosynthesis and nutrient contents in cucumber seedlings. Not. Bot. Horti Agrobot. Cluj-Napoca 2020, 48, 116-127. [CrossRef]

40. Osmond, B.; Badger, M.; Maxwell, K.; Björkman, O.; Leegood, R. Too many photons: Photorespiration, photoinhibition and photooxidation. Trends Plant Sci. 1997, 2, 119-121. [CrossRef]

41. Simon, E.W. Phospholipids and plant membrane permeability. New Phytol. 1974, 73, 377-420. [CrossRef]

42. Lutts, S.; Benincasa, P.; Wojtyla, L.; Kubala, S.; Pace, R.; Lechowska, K.; Garnczarska, M. Seed priming: New comprehensive approaches for an old empirical technique. In New Challenges in Seed Biology: Basic and Translational Research Driving Seed Technology; Araújo, S., Balestrazzi, A., Eds.; IntechOpen: Rijeka, Croatia, 2016; pp. 1-46.

43. Kubala, S.; Wojtyla, L.; Garnczarska, M. Seed priming improves salt stress tolerance during germination by modulation of antioxidative capacity. BioTechnologia 2013, 94, 223.

44. Kubala, S.; Garnczarska, M.; Wojtyla, Ł.; Clippe, A.; Kosmala, A.; Żmieńko, A.; Lutts, S.; Quinet, M. Deciphering priming-induced improvement of rapeseed (Brassica napus L.) germination through an integrated transcriptomic and proteomic approach. Plant Sci. 2015, 231, 94-113. [CrossRef]

45. Kibinza, S.; Bazin, J.; Bailly, C.; Farrant, J.M.; Corbineau, F.; El-Maarouf-Bouteau, H. Catalase is a key enzyme in seed recovery from ageing during priming. Plant Sci. 2011, 181, 309-315. [CrossRef]

46. Fallah, S.; Malekzadeh, S.; Pessarakli, M.; Fallah, S. Seed Priming Improves Seedling Emergence and Reduces Oxidative Stress in Nigella Sativa under Soil Moisture Stress. J. Plant Nutr. 2017, 41, 29-40. [CrossRef]

47. Bharuth, V.; Naidoo, C. Responses to cryopreservation of recalcitrant seeds of Ekebergia capensis from different provenances. S. Afr. J. Bot. 2020, 132, 1-14. [CrossRef]

48. Pammenter, N.W.; Adamson, J.H.; Berjak, P. Viability of Stored Seed: Extension by Cathodic Protection. Science 1974, 186, 1123-1124. [CrossRef] [PubMed]

49. Berjak, P. Viability extension and improvement of stored seeds. S. Afr. J. Sci. 1978, 74, 365-368.

50. Naidoo, S. Studies on Factors Influencing Viability after Cryopreservation of Excised Zygotic Embryos from Recalcitrant Seeds of Two Amaryllid Species. Ph.D. Dissertation, University of KwaZulu-Natal, Durban, South Africa, 2010.

51. Gebashe, F.C. Studies on the Cryopreservation of Shoot Apices from Recalcitrant-Seeded Trichilia emetica Vahl. and Trichilia dregeana Sond. Ph.D. Dissertation, University of KwaZulu Natal, Durban, South Africa, 2015.

52. Zhang, H.; Mittal, N.; Leamy, L.J.; Barazani, O.; Song, B.-H. Back into the wild-Apply untapped genetic diversity of wild relatives for crop improvement. Evol. Appl. 2016, 10, 5-24. [CrossRef] [PubMed]

53. Jorgenson, A.K.; Burns, T.J. Effects of Rural and Urban Population Dynamics and National Development on Deforestation in Less-Developed Countries, 1990-2000. Sociol. Inq. 2007, 77, 460-482. [CrossRef]

54. FAO; IFAD; UNICEF; WFP; WHO. The State of Food Security and Nutrition in the World 2018. Building Climate Resilience for Food Security and Nutrition; FAO: Rome, Italy, 2018. 